\title{
The Relationship between Ferritin and Calcium Levels in Patients with Thalassemia $\beta$ Major
}

\author{
Nurdin Aji Iskandar, Harsono Salimo, Annang Giri Moelyo \\ Department of Pediatrics, Faculty of Medicine, Universitas Sebelas Maret/ \\ Dr. Moewardi Hospital, Surakarta
}

\section{ABSTRACT}

Background: Thalassemia is a hereditary disease in which the sufferer is unable to produce sufficient amounts of hemoglobin, causing impaired function of red blood cells and shortened red blood cell age. Thalassemia sufferers are spread all over the world, and thalassemia is one of the health problems in the world. Therapy in patients with thalassemia is with routine blood transfusions. One side effect of repeated transfusions is iron overload which causes deposits of iron in the endocrine glands. This study aimed to determine the relationship between ferritin levels with blood calcium levels in patients with $\beta$ major thalassemia.

Subjects and Method: This was a cross-sectional study conducted at Dr. Moewardi, Surakarta, from June to November 2017. Samples of 49 patients with thalassemia $\beta$ major aged 5-10 years were selected using consecutive sampling. The dependent variable is blood calcium levels.
The independent variable is ferritin level. Data were analyzed with Chi Square test.

Results: High ferritin levels reduce calcium level in pediatric thalassemia $\beta$ major patients, but not statistically significant $(\mathrm{OR}=0.27 ; 95 \% \mathrm{CI}=0.04$ to $1.64 ; \mathrm{p}=0.134$ ).

Conclusion: High ferritin levels decrease with calcium levels in pediatric thalassemia $\beta$ major patients, but not statistically significant.

Keywords: ferritin, calcium, thalassemia $\beta$ major

\section{Correspondence:}

Andhika Trisna Putra. Department of Pediatrics, Faculty of Medicine, Universitas Sebelas Maret/ Dr. Moewardi Hospital, Surakarta. Telpon/Fax.0271-633348, Email: andhika.pediatric@gmail.com.

\section{Cite this as:}

Iskandar NA, Salimo H, Moelyo AG (2020). The Relationship between Ferritin Levels and Calciumin Patients with Thalassemia $\beta$ Major. Indones J Med. 05(02): 137-141. https://doi.org/10.26911/theijmed.2020.05.02.07 cC) (i) (-) Indonesian Journal of Medicine is licensed under a Creative Commons EY NC SA Attribution-NonCommercial-ShareAlike 4.o International License.

\section{BACKGROUND}

Thalassemia is a disease that has spread throughout the world, and is one of the world's health problems. Thalassemia causes anemia and requires routine blood transfusions. Meanwhile, in Indonesia the number of thalassemia patients until 2009 rose to 8 , $3 \%$ from 3,653 patients recorded in 2006 (Capellini et al., 2014).

One side effect of repeated transfusions is iron overload which causes deposits of iron in the endocrine glands and important organs such as the heart and kidneys. One parameter that can be used to assess iron overload is serum ferritin levels (Nancy, 2014; Leecharoenkiat, 2016).

Several studies in Saudi Arabia reported the prevalence of hypocalcemia in betathalassemia major patients increased from $21 \%$ to $41 \%$ from 2000 to 2008 (Aleem et al., 2000; Najafipour et al., 2008).

In 2012, the incidence of hypocalcemia in Iran patients with beta major thalassemia was reported to be at 22\% (Mirhosseini et al., 2013). There is a relationship between ferritin levels with hypocalcemia in patients with thalassemia $\beta$ major. However ferritin levels are not related to PTH levels and vitamin D (Aleem et al., 2000; Adil et al., 2012). This 
Iskandar et al./ Ferritin and Calcium Levels in Patients with Thalassemia $\beta$ Major

study aims to determine the relationship between ferritin levels with blood calcium levels in patients with $\beta$ major thalassemia.

\section{SUBJECTS AND METHOD}

\section{Study Design}

This study was an observational analytic cross-sectional design conducted at the Hospital Dr. Moewardi Surakarta, Java, Central.

\section{Population dan Sample}

The target population is pediatric patients with thalassemia $\beta$ major. Affordable population is pediatric thalassemia major $\beta$ patients who are in Dr. Moewardi Hospital Surakarta between June 2017 to November 2017. The sample was 49 patients with $\beta$ major thalassemia aged 5-10 years who were selected by consecutive sampling.

\section{Study Variables}

The dependent variable is calcium levels. The independent variable is ferritin content.

4. Operational Definition of Variables Calcium level was examined by the ion selective electrode method using the ROCHE 9180 Eletrolyte Analyzer machine.

Blood ferritin levels were calculated by the ELISA method using the VIDAS machine. Nutritional status was determined by measuring Mid-upper Arm Circumference (MUAC). The measurement were expressed in centimeters and plot into the MUAC curve according to age.

SGOT and SGPT levels were examined using enzymatic methods using Siemens Advia 1800.

\section{Study Instruments}

All children who met the inclusion criteria were taken as research subjects. Parents/ guardians of the research subjects were given an explanation and requested written approval. Data is taken from interviews with parents/guardians and from medical records regarding the history of current illness, and recall diets. Analysis of the relationship bet- ween ferritin levels and calcium levels was also carried out.

\section{Data Analysis}

Characteristics of continuous data samples are described in n, mean, and SD. Characteristics of categorical data samples are described in $\mathrm{n}$ and\%. Comparison of ferritin levels (\%) and calcium levels (\%) were analyzed by Chi square test.

\section{Research Ethic}

This study was approved by the Board of Health Research Ethics Commission of Dr. Moewardi Hospital / Sebelas Maret University School of Medicine Number: 851/X/ HRE$\mathrm{C} / 2017$.

\section{RESULTS}

A. Univariate analysis

Table 1 shows the characteristics of continuous data sample data. Table 1 shows that the level of ureum in patients with thalassemia $\beta$ major average 20.48 (Mean $=20.48$; $\mathrm{SD}=6.94$ ), mean creatinine level is 0.47 (Mean = 0.47; $\mathrm{SD}=0.97$ ), average SGPT level is 50.61 (Mean=50.61; $\mathrm{SD}=39.47)$, the average $\mathrm{SGOT}$ level is $47.22(\mathrm{Mean}=47.22 ; \mathrm{SD}=$ 62.23), the average calcium level is 1.20 (Mean=1.20; $\mathrm{SD}=0.10$ ), and the average ferritin level is 3,112.24 (Mean = 3,112.24; $\mathrm{SD}$ $=1,647 \cdot 15$ ).

Table 2 shows the characteristics of categorical data samples. Table 2 shows that the majority of patients were female (63.3\%), and had normal nutritional status (65.3\%).

\section{$B$. The result of bivariate analysis}

Table 3 shows the results of comparison of ferritin levels with calcium levels in pediatric patients with thalassemia major at Dr Moewardi Hospital Surakarta. Patients with high ferritin levels tend to have low calcium levels (34.88\%) compared to patients with normal ferritin levels (66.67\%).

High ferritin levels reduce calcium levels 0.27 times than normal ferritin levels 
Iskandar et al./ Ferritin and Calcium Levels in Patients with Thalassemia $\beta$ Major

$(\mathrm{OR}=0.27 ; 95 \% \mathrm{CI}=0.04$ to $1.64 ; \mathrm{p}=0.134)$

Table 1. Characteristics of Samples (Continuous Data)

\begin{tabular}{lcc}
\hline Characteristics & Mean & SD \\
\hline Ereum & 20.48 & 6.94 \\
Creatinine & 0.47 & 0.97 \\
SGPT & 50.61 & 39.47 \\
SGOT & 47.22 & 62.23 \\
Calcium intake & 346 & 429 \\
Calcium & 1.20 & 0.10 \\
Ferritin $(\mathrm{ng} / \mathrm{dl})$ & $3,112.24$ & $1,647.15$ \\
\hline
\end{tabular}

Table 2. Sample Characteristics (Categorical Data)

\begin{tabular}{lcc}
\hline Characteristics & n & \% \\
\hline Gender & & \\
$\quad$ Female & 31 & $63.3 \%$ \\
Male & 18 & $36.7 \%$ \\
Nutritional Status & & \\
$\quad$ Lacking & 17 & $34.7 \%$ \\
$\quad$ Normal & 32 & $65.3 \%$ \\
\hline
\end{tabular}

Table 3. Chi Square Test of Ferritin Levels and Calcium Levels

\begin{tabular}{|c|c|c|c|c|c|c|c|c|}
\hline \multirow{3}{*}{$\begin{array}{l}\text { Ferritin } \\
\text { Level }\end{array}$} & \multicolumn{4}{|c|}{ Calcium Level } & \multirow{3}{*}{ OR } & \multicolumn{2}{|c|}{ 95\% CI } & \multirow{3}{*}{$\mathbf{p}$} \\
\hline & \multicolumn{2}{|c|}{ Normal } & \multicolumn{2}{|c|}{ Low } & & Lower & Upper & \\
\hline & $\mathbf{n}$ & $\%$ & $\mathbf{n}$ & \% & & Limit & Limit & \\
\hline Normal & 2 & 33.33 & 4 & 66.67 & 0.27 & 0.04 & 1.64 & 0.134 \\
\hline High & 28 & 65.12 & 15 & 34.88 & & & & \\
\hline
\end{tabular}

\section{DISCUSSION}

Data characteristic samples showed that of 49 patients, there were 43 patients who had high serum ferritin, and 6 patients had normal serum ferritin. The majority of patients with high serum ferritin is in accordance with several previous studies which showed that patients with B-Thalassemia have higher serum ferritin than healthy people (Attia et al., 2011; Karim et al., 2016;). There are 6 respondents who have normal serum ferritin suspected to be caused by blood transfusion factor itself, as described in a study (Taher and Saliba, 2017). First, it is possible that patients who have low serum ferritin are transfused-dependent thalassemia patients, but have not been transfused for a long time, giving the body time to excrete ferritin. Secondly, it is possible that there are patients who have a profile as thalassemia patients who are not transfusion dependent, so that the patient's serum ferritin does not increase.

Previous research states that patients with B-Thalassemia have lower calcium levels than normal patients (Karim et al., 2016). A study also showed that patients with BThalassemia will experience hypoparathyroidism where the lack of PTH production will reduce the absorption of calcium from the gastrointestinal tract and reduce calcium levels in serum (Lertsuwan et al., 2018). Other studies have also shown that patients without blood disorders will have better bone density than patients with blood disorders (Lee et al., 2013). The same research also explains that there are several other factors that can influence calcium levels in a person. First, a higher calcium intake in a person will increase calcium levels in that person. The absence of dietary restrictions or calcium diet questionnaires to determine the calcium intake of 
respondents allegedly caused a high percentage of respondents with normal calcium. Second, it is a factor of the PTH hormone. The absence of examination of PTH levels and restriction of respondents with normal parathyroid function is thought to have caused the inclusion of respondents with normal serum PTH. Normal PTH serum, will cause calcium in the blood is relatively normal (Song, 2017).

\section{AUTHOR CONTRIBUTION}

Nurdin Aji Iskandar, Harsono Salimo, Annang Giri Moelyo, collected the data, measured MUAC, calsium and feritin levels, did data analysis, interpreted the results, and wrote the paper.

\section{CONFLICT OF INTEREST}

There is no conflict of interest in this study.

FUNDING AND SPONSORSHIP

This study is self-funded.

\section{ACKNOWLEDGEMENT}

The author would like to thank all those who have helped this research, namely to patients and parents of research subjects, Head of Room and Nurse of Melati 2 Room, Clinical Pathology Laboratory of Dr. Moewardi Hospital in Surakarta, as well as all those who helped to carry out this research.

\section{REFERENCE}

Adil A, Sobani ZA, Jabbar A, Adil SN, Awan $\mathrm{S}(2012)$. Endocrine complications in patients of beta thalassemia major in a tertiary care hospital in Pakistan. J Pak Med Assoc. 2012; 62:307-10. https://www.ncbi.nlm.nih.gov/pubmed/22764480

AleemA, Al-Momen AK, Al-Harakati MS, Hassan A, Al-Fawaz I (2000). Hypocalcemia due to hypoparathyroidism in $\beta$ thalassemia major patients. Annals of
Saudi Medicine. 20(5): 364-6. https://doi.org/10.5144/0256-4947.2000.364

Attia A, Sayed AM, Ibrahim F, Mohammed AS, Elalfy MS (2011). Effects of antioxidant vitamins on the oxidant/antioxidant status and liver function in homozygous beta-thalassemia. Romanian J. Biophys. 21: 93-106.

Capellini MD, Cohen A, Porter J, Taher A, Viprakasit V (2014). Hypoparathyroidism (HPT). In: Guidelines for the management of transfusion dependent thalassemia. https://www.resonancehealth.com/images/files/clinician-information/patient-management-guidelines/TIF\%20Guidelines\%2ofor\%20the\%2oManagement\%20of\%20Transfusion\%20Dependent\%20Thalassaemia.pdf

Karim MF, Ismail M, Hasan AM, Shekhar HU (2016). Hematological and biochemical status of Beta-thalassemia major patients in Bangladesh: A comparative analysis. Int $J$ Hematol Oncol Stem Cell Res. 10(1):7-12. https://www.ncbi.nlm.nih.gov/pubmed/27047645

Lee KS, Jang JS, Lee DR, Kim YH, Nam GE, Do Han K et al. (2013). Serum ferritin levels are positively associated with bone mineral density in elderly Korean men: the 2008-2010 Korea National Health and Nutrition Examination Surveys. J Bone Miner Metab. 32(6): 683690. https://doi.org/10.1007/s00774013-0540-Z

Leecharoenkiat K, Lithanatudom P, Sornjai W, Smith DR (2016). Iron dysregulation in beta-thalassemia. Asian Pacific $\mathrm{J}$ Trop Med. 9:1035-43. https://doi.org/10.1016/j.apjtm.2016.07.035

Lertsuwan K, Wongdee K, Teerapornpuntakit J, Charoenphandhu N (2018). Intestinal calcium transport and its regulation in thalassemia: interaction between calcium and iron metabolism. J Phy- 
Iskandar et al./ Ferritin and Calcium Levels in Patients with Thalassemia $\beta$ Major

siol Sci. 68(3): 221-232. https://doi.org/10.1007/s12576-018-0600-1

Mirhosseini NZ, Shahar S, Ghayour-Mobarhan M, Banihashem A, Kamaruddin NA, Hatef MR, Esmaili HA (2013). Bonerelated complications of transfusiondependent beta thalassemia among children and adolescents. J Bone Miner Metab. 31(4): 468-76. https://doi.org/10.1007/s00774-013-0433-1

Najafipour F, Aliasgarzadeh A, Aghamohamadzadeh N, Bahrami A, Mobasri M, Niafar M, Khoshbaten M (2008). A cross-sectional ttudy of metabolic and endocrine complications in beta-thalassemia major. Ann Saudi Med. 28(5): 361-66. https://doi.org/10.5144/o2564947.2008.361

Song L (2017). Calcium and Bone Metabolism Indices. Adv Clin Chem. 82: 1-46. https://doi.org/10.1016/bs.acc.2017.06.005

Taher AT, Saliba AN (2017). Iron overload in thalassemia: Different organs at different rates. Hematology Am Soc Hematol Educ Program. 2017(1): 265-271. https://doi.org/10.1182/asheducation2017.1.265 